\title{
A QUALITATIVE APPROACH FOR SPATIAL MULTI-CRITERIA EVALUATION OF LANDSLIDE SUSCEPTIBILITY BY NORMALISED VALUES OF ANALYTICAL HIERARCHICAL PROCESS (AHP): A CASE STUDY FROM KALAWANA ADMINISTRATIVE DIVISION, SRI LANKA
}

\author{
A. A. VIRAJH DIAS ${ }^{1,3^{*}}$, JAGATH GUNATILAKE ${ }^{2,3}$ \\ ${ }^{1}$ Central Engineering Consultancy Bureau, Colombo 7, Sri Lanka. \\ ${ }^{2}$ Department of Geology, Faculty of Science, University of Peradeniya, Sri Lanka. \\ ${ }^{3}$ Postgraduate Institute of Science, University of Peradeniya, Sri Lanka \\ *Corresponding author e-mail: aavirajhd@yahoo.com \\ (Recieved $29^{\text {th }}$ January 2019; Accepted $10^{\text {th }}$ Fabruary 2019)
}

\begin{abstract}
The qualitative evaluation of large databases and determination of significance of multivariate databases is a prominent approach. Numerical methodologies of data evaluation has yet to uncover many exciting opportunities for application in disaster management. The evaluation of landslide susceptibility usually deals with various combinations of geographical data sets including slope forms, catchment hydrology, stream hydrology, precipitation potential or rainstorm, soil saturation, soil strength, saturation potential and various derived forms of geological data. The difficulties associated with introducing a large data integrated system are first, having a systematic evaluation methodology which is practical, and second, having a set of scientific auxiliary decision methods to evaluate total significance. The Analytical Hierarchical Process (AHP) is a convenient way for quantitative analysis in decision making under a probabilistic environment and it is also an effective method for scientists to objectively provide subjective judgment. The AHP improves qualitative approaches on mutually exclusive dependencies or interdependencies of data and evaluates the significance in the Weighted Average Analysis (WAA) approach on landslide susceptibility. This qualitative approach will be further used to calibrate the large databases on landslide susceptibility evaluation with more and more interacting sets of data. The overall accuracy of the WAA model approach always depends on the sensitivity of the GIS databases and calibration through physically known datasets of landslide occurrences.
\end{abstract}

Keywords: Landslides, Susceptibility, Analytical Hierarchical Approach (AHP)

\section{INTRODUCTION}

Landslides and slope degradation processes are natural and frequently occurring events since the start of human civilization. A poststorm hazard assessment report of the Ratnapura District, Sri Lanka (CECB Report, 2003) was conducted by the Central Engineering Consultancy Bureau in May 2003 on the biggest disaster event recorded in the history of floods and landslide in Sri Lanka. Many buildings were submerged. Several of those killed were buried alive in landslides. There were total of 316 reported landslides in Ratnapura District, which were studied under the above assessment. The landslide distribution in each Grama Niladari Divisions (GND) of the Ratnapura District is shown in 
Fig. 1. In addition, rains accompanied by heavy winds left an estimated 247 dead, over 200,000 families displaced, thousands of houses damaged and outstanding infrastructure facilities totally destroyed during May 2003. The worst affected areas were Kalawana division of the Ratnapura district and parts of the Galle, Matara, Kalutara and Hambantota districts.

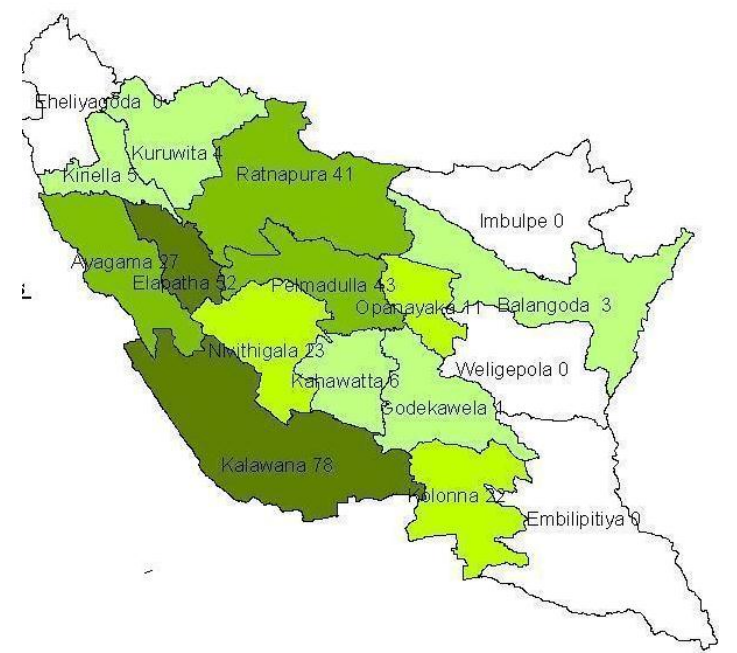

Fig. 1. Landslide distribution in Grama Niladari Divisions(GND) of the Ratnapura district, 2003.

Landslides were reported from villages of Ratnapura, Elapatha, Thotagamuwa, Hangamuwa, Palawela, Dambuluwana, Karangoda, Muwagama, Godigamuwa and Getangama on the Colombo-Ratnapura Road. More than 140,000 people were evacuated to schools and temples, and helicopters dropped emergency rations on villages that were cut off from assistance. Despite technological progress and better understanding and forecasting of natural processes, material damage due to hydrological extremes has not decreased (AGS, 2007b). Relatively large natural slope failures are one of the major hazards occurring each year under rainstorm conditions and leads to enormous property damage in terms of both direct and indirect costs. Landslides are defined as a movement of a mass of rock, debris or soil earth down slope due to gravitation (AGS, 2007c, AGS, 2007a), and can be triggered by a variety of extrinsic factors including intense rainfall, earthquake, seismicity, (Vitanage, 1994) storm waves and rapid stream erosion that causes rapid increases in adverse stresses and decreases the shear strength of slope forming materials (Dias et al., 2014).

The various methodologies described the landslide disaster potential with factor overlay criteria but with the introduction of new sets of landslide databases similar to the event of 2003, landslide susceptibility criteria needs updating methodologies to increase accuracy. The main objective of landslide susceptibility mapping is to find out the unstable region by studying the factors that affect the occurrence of landslides (Shahabi et al., 2012; khezri et al., 2013). Susceptibility is defined as the relative proneness of the terrain to produce slope failures (Ramachandra et al., 2012; Feizizadeh et al., 2013). A landslide susceptibility map indicates areas likely to undergo landslides in the future by correlating various forms of intrinsic or extrinsic (mostly geographical factor) that contribute to produce landslides with the past distribution of slope failures (Van Westen, 2000; Moradi et al., 2012). Therefore, one of the most prominent numerical approaches of Analytical Hierarchical Process (AHP) is used for quantitative analysis in decision making for spatial multi criteria evaluation and it is also an effective method for scientists to objectively provide subjective judgment. Therefore, the AHP improves qualitative approaches on the significance in the WAA approach on landslide susceptibility.

\section{STUDY AREA AND DATA}

The Kalawana Division is located in the South-Western part of Sri Lanka in the province of Sabaragamuwa, the so-called wet zone of the country and was the worst affected area during the heaviest rainfall on $17^{\text {th }}$ May 2003. The study area focuses on the Kalawana Administrative Division (see Fig. 3) which belongs to the Sabaragamuwa Province in Sri 
Lanka. It runs from $6^{\circ} 35^{\prime} 30^{\prime \prime}$ To $6^{\circ} 22^{\prime} 20^{\prime \prime}$ Northern latitude and from $80^{\circ} 38^{\prime} 25^{\prime \prime}$ To $80^{\circ} 17^{\prime 2} 23^{\prime \prime}$ Eastern longitude. Most of the landslide initiation points are inaccessible due to difficult terrain and weather. The study was further extended by a selected 39 locations which were physically accessible, acquiring GPS data/mapping and soil sampling for the determination of soil strength parameters and such detailed assessment was conducted during the period of 2008-2009. All data were tabulated according to the thirty subcathments as difined in the base map of the Kalawana administrative division of the Ratapura District as shown in Fig. 2.

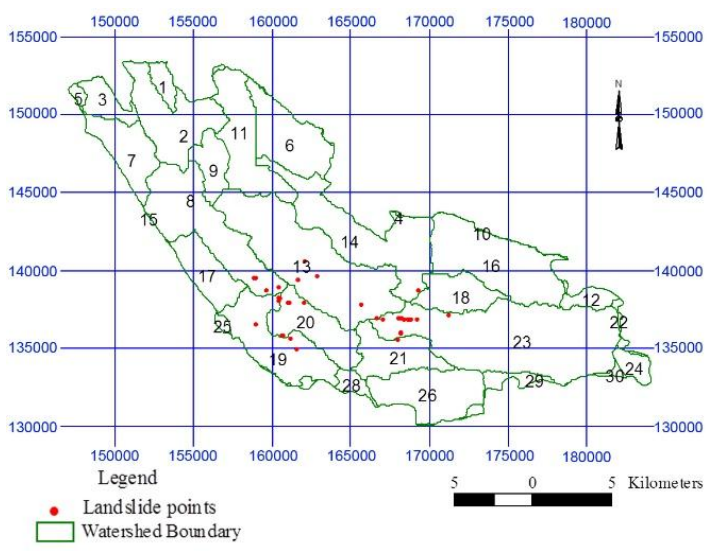

Fig. 2. Data evaluation base map for Kalawana Division. The map further disintegrated into thirty sub watersheds before utilizing the factor overlay method of assessment.
The Fig. 3 \& Fig. 4 shows the administrative area, major townships and major watershed of Kukule Ganga within the Kalawana administrative division.

\section{SHALLOW LANDSLIDES}

A landslide in which the sliding surface is located within the surface deposition or in a highly weathered rock form with a typical depth from few decimetres to some meters can be defined as a shallow landslide (AGS, 2007c, AGS, 2007a). Typical observations meet with failures of road cut-slopes, watersheds of first order stream, thin overburden soil seated on bedrock with dipping towards slope or instability of slope due to removing of lateral support due to various human interventions in hill slope developments as similar to the Fig.5 to Fig 8. Shallow landslides can often happen in areas that have slopes with low permeability of bottom soils due to various geological conditions. In addition, development of perch water table or sudden increases of pore water pressure during high rainfall tends to initiate movement of shallow depths of soil masses outward from its locality. The low permeable, bottom soils trap the water in the shallower, and tends to decreases of shear strength of soil.

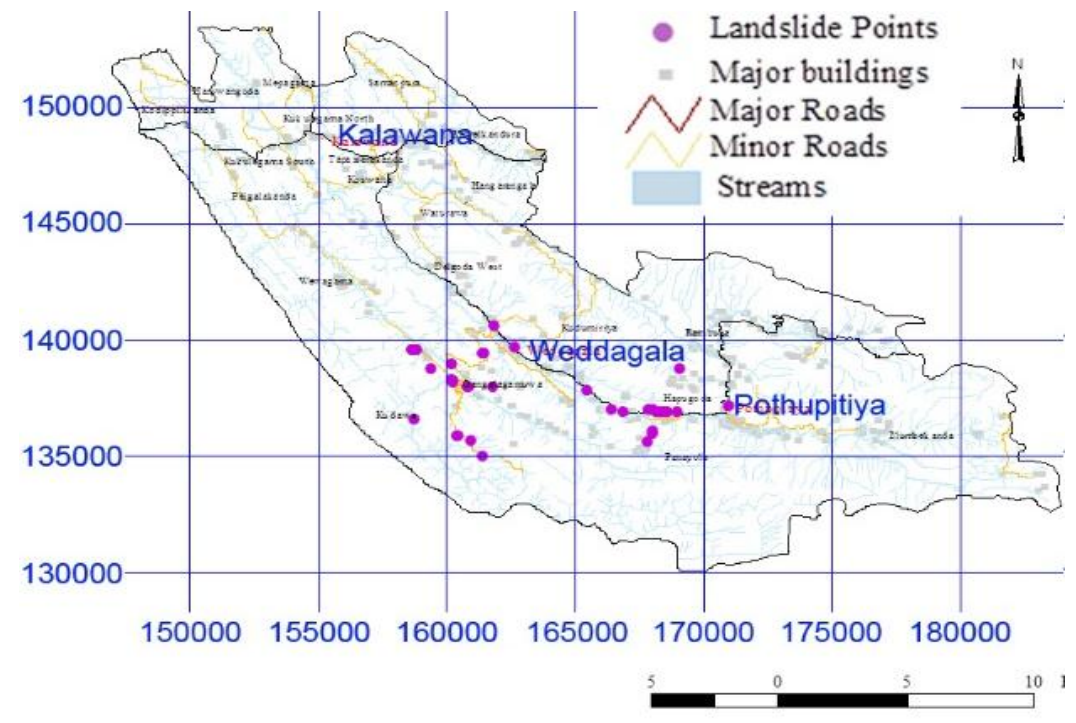

Fig. 3. The Kalawana administrative division of the Ratnapura district. 


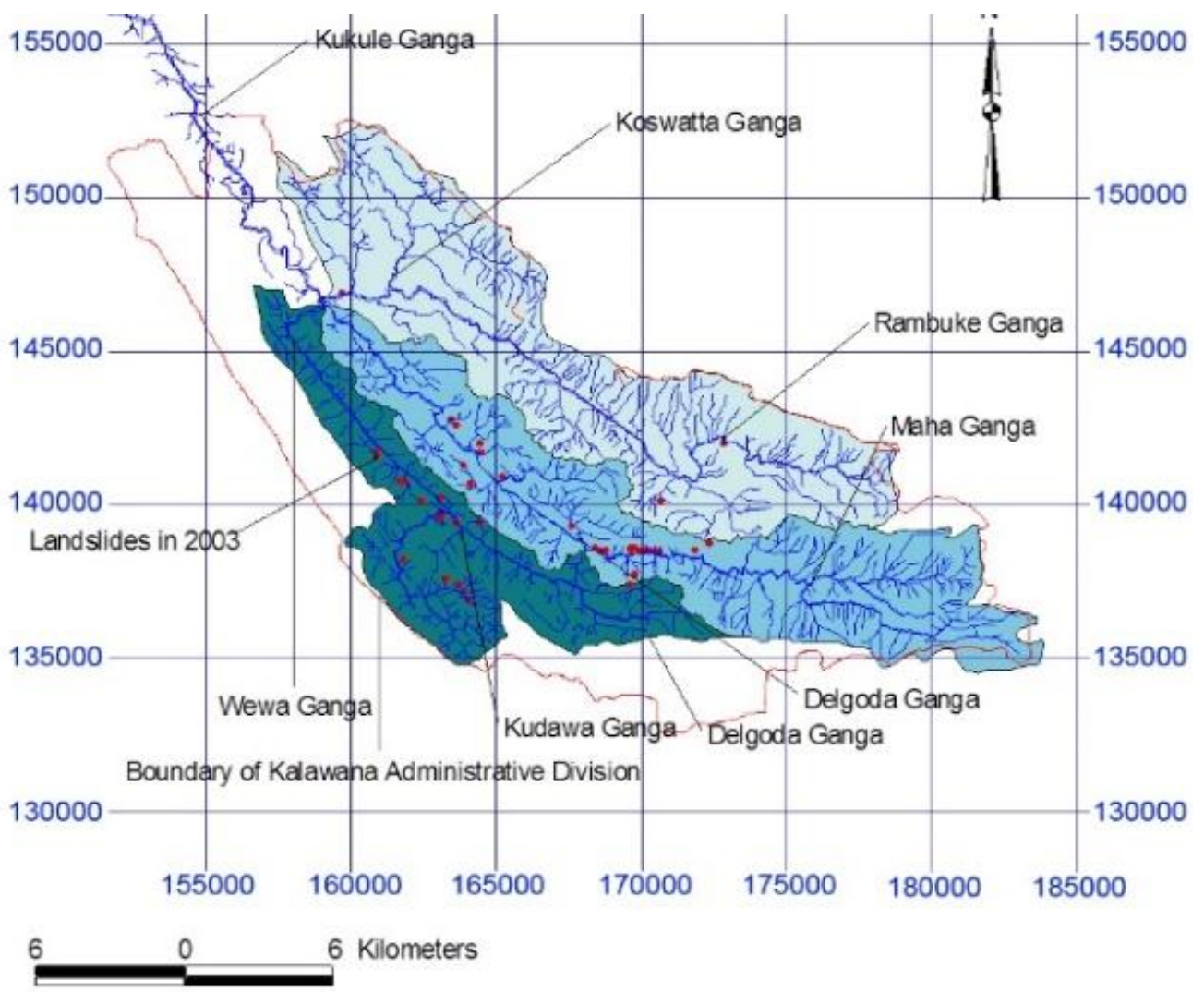

Fig. 4. Kukule Ganga watershed and the Kalawana administrative division.

If permeability decreases with depth, a perched water table may develop in soils during intense precipitation (Campbell, 1975) and can create more tendency to shallow land sliding. There is little evidence to demonstrate systematic variation in slide intensity with bedrock lithology and significant variations in shallow sliding can be noticed in various soil and vegetation types (Brumbaugh, 1980) on the overburdened slope. The temporal patterns of landslides do not show direct association between vegetation removal and increased landslides. But large human interventions associated with hill country developments are directly associated with increases of water ingress and increases the instability potential of shallow landslides. (Cooray, 1994) The planar failure and circular behaviour are prominent in landslides in clay soil and residual soils and depths of failure circles usually do not exceed 4 to $6 \mathrm{~m}$ (Bhandari and Dias, 1996).
Some continue to exhibit intermittent, relatively slow deformations with limited mobility. In some instances, these suddenly develop into a catastrophic failure, with extremely rapid flow slides having various ombination of soils and rock, also noticed as having shallow depth but relatively long and continuous (Cruden and Varnes, 1996).

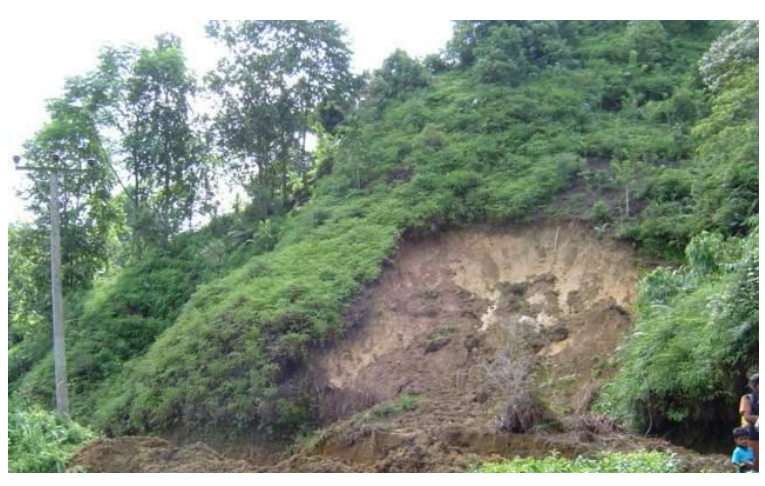

Fig. 5. Lanslide activation noticed in abondand tea cultivated area. 


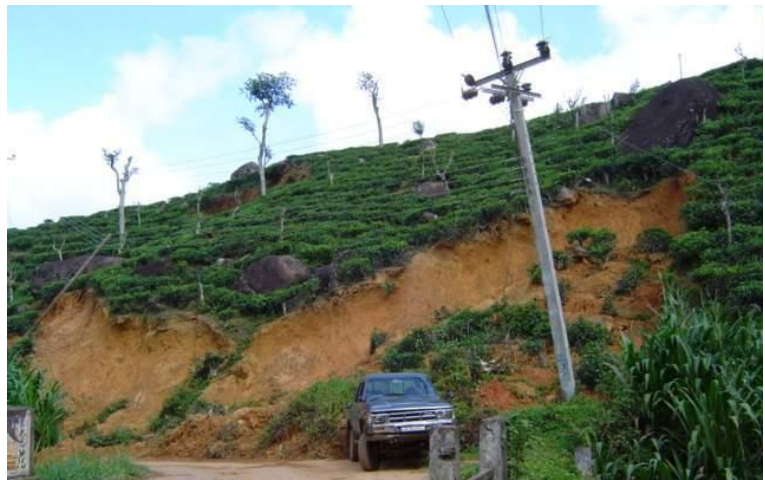

Fig. 6. Failure in road adjoining cut slope.

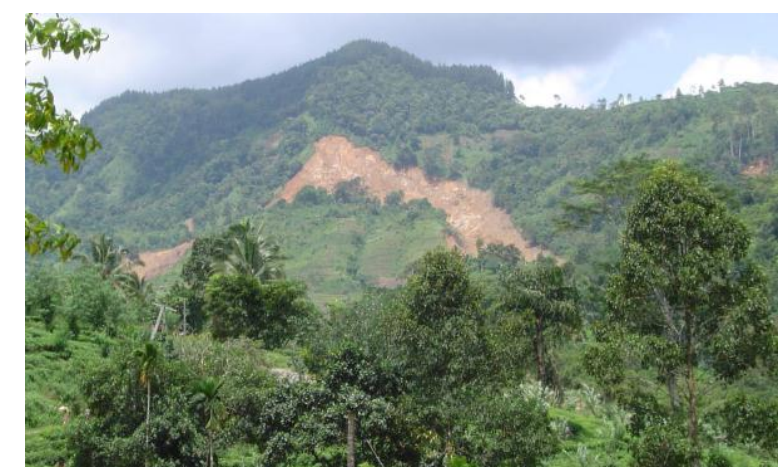

Fig. 7. Geological instabilities in hill slopes in Ratnapura district.

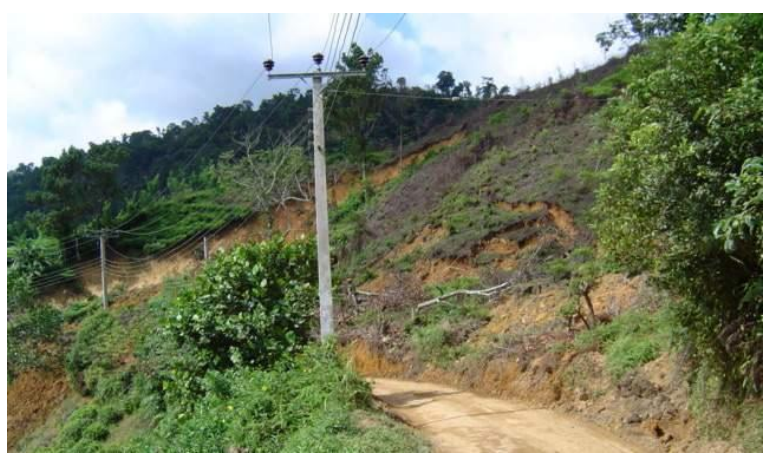

Fig. 8. Development of potential instabilities within road buffer area due to heavy rains

\section{METHODALOGY}

\section{WEIGHTED AVERAGE ANALYSIS (WAA) APPROACH}

According to Carrara et al., 1998 approaches for landslide hazard assessment can generally be grouped into two main categories: the direct, qualitative method that relies on the ability of the investigator to estimate actual and potential slope failures by incorporating investigated parameters in a specific two dimensional profile, and indirect, quantitative methods that produce numerical estimates (probabilities) of the occurrence of landslide in any hazard zone. The choice of the method mainly depends on the spatial scale (Van Westen, 2000) and thus, the data availability. To assess landslide susceptibility on a regional scale, multivariate statistical approaches were commonly used in the last decades. Therefore, landslide susceptibility analysis requires validity and prominence of individual factors responsible for the slope instability and that could be used in place of weighted average analysis. These individual factors contribute in differing degrees of hazard and has led to the development of landslide susceptibility maps (Varnes, 1978). The degree of hazard is considered relative since it represents the expectation of future landslide occurrence based on the physical conditions of the area. These are slope maps derived from the DEM, bedrock geology maps, landuse maps derived from aerial photos, soil maps derived from the average combined cohesion concept (i.e. root cohesion and soil cohesion), derived maps of road buffer from slopes, rainfall maps and stream density maps. Rainfall is the primary triggering factor in most slope instability problems on hill slopes. Therefore, hydrological parameters (rainfall and stream density) were considered to obtain reasonably accurate weights for the analysis. Three day cumulative rainfall distribution patterns in a particular watershed and the total number of $1^{\text {st }}$ order streams in the watershed were considered. The Weighted Average Analysis (WAA) technique, being the most appropriate methodology adopted in Geographical Information Systems (GIS), is ideally suited for evaluation and interpretation of landslide susceptibility analysis which can be adopted for use with even inaccessible mountainous regions where a majority of old landslides are identified. The schematic diagram of the overall method of approach is given in Fig. 9 and base map with thirty number of sub divisions of Kalawana main watershead is shown in Fig. 2. 


\section{GIS Based Multi Criteria Analysis (Weighted Average Analysis)}

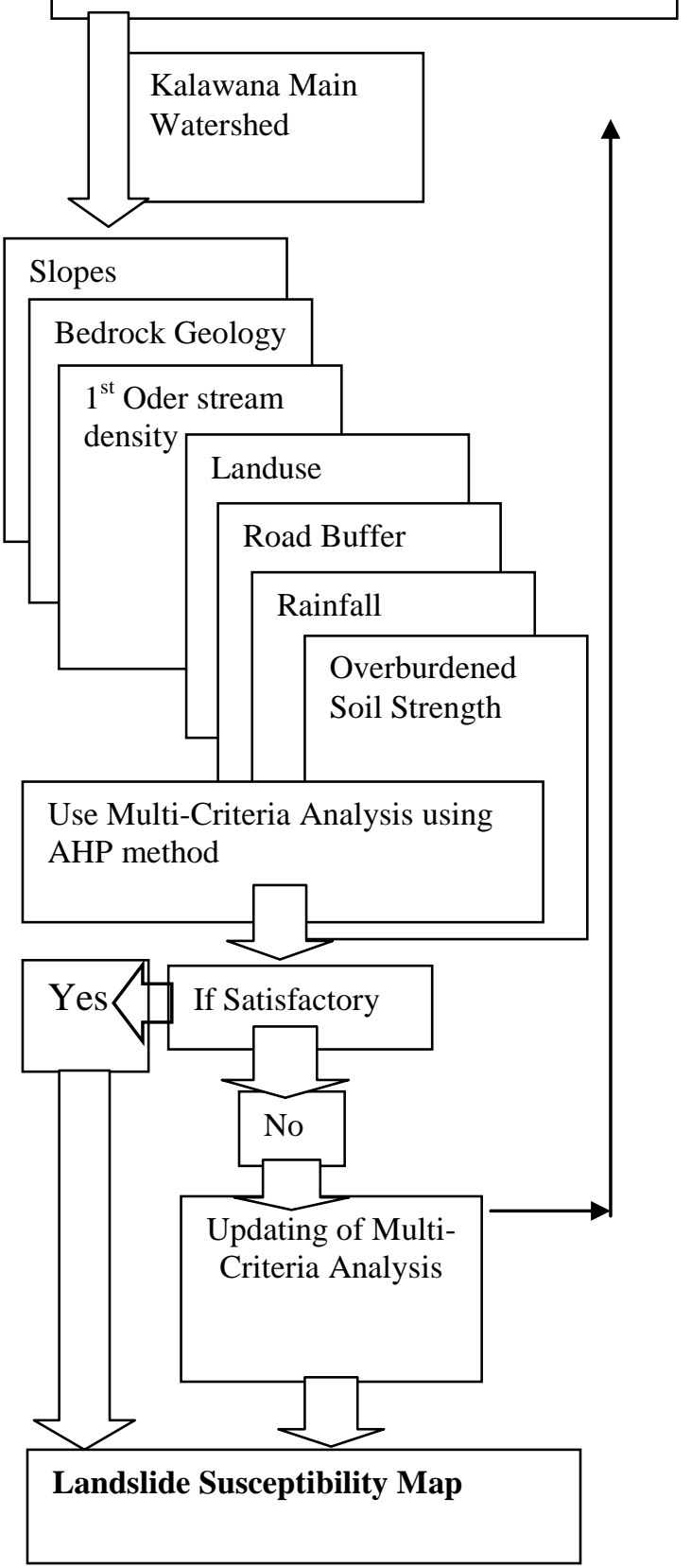

Fig. 9. Schematic diagram of the approach methodology.

All factor maps were generated and evaluated against the sub category of selected factor maps and the evaluation was made for landslide significance of each factor as shown in Fig 10 to Fig. 16.

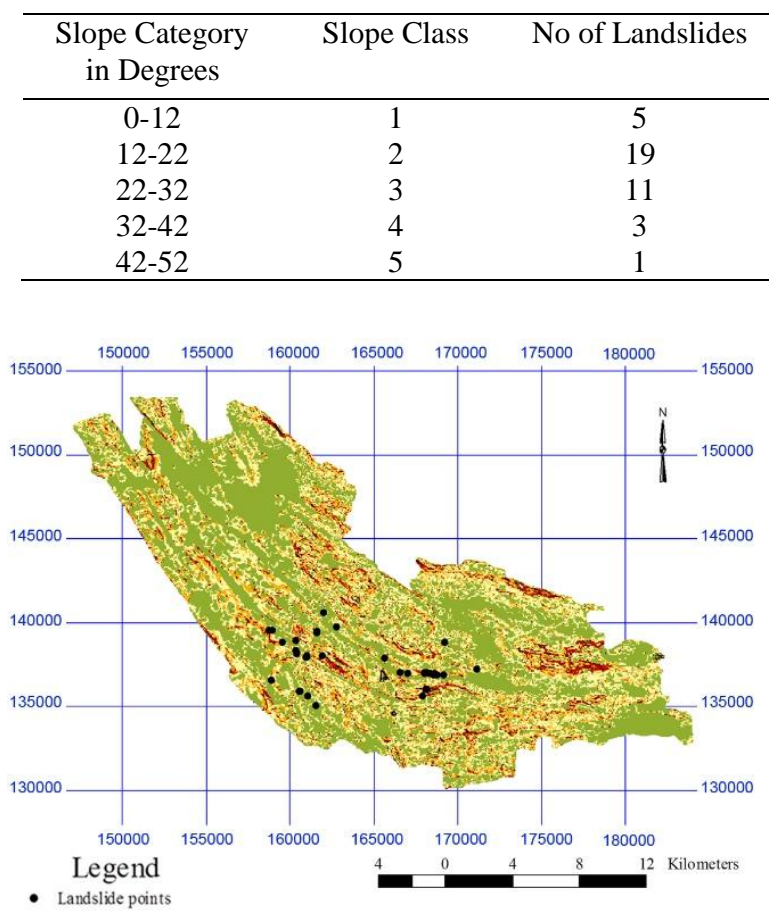

Fig. 10. Relationship with the slope class (Slope category in Degrees) and landslide occurrence in Kalawana watershed.

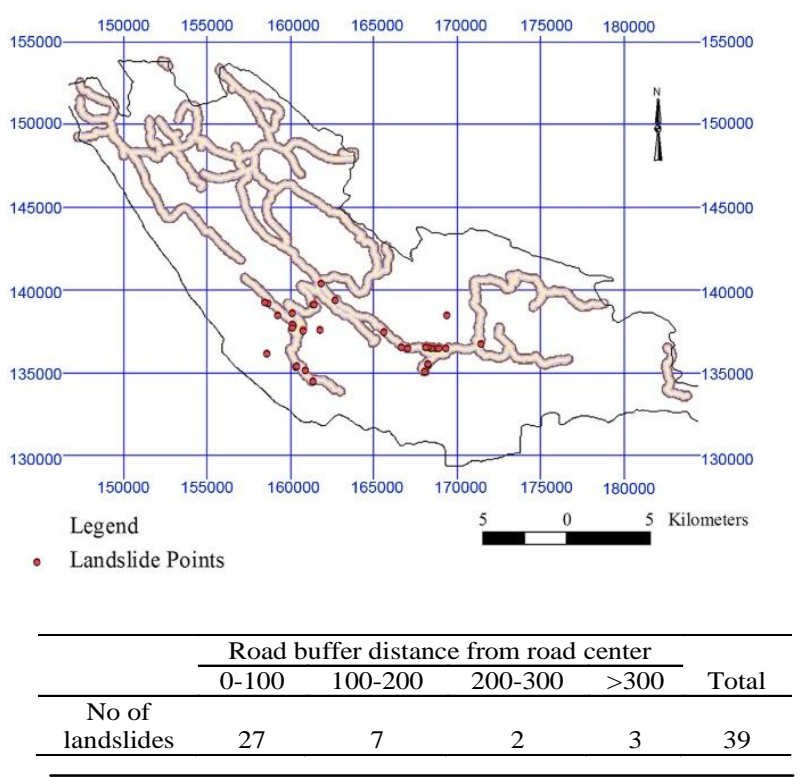

Fig. 11: Relationship with the road buffer distance from center and landslide occurrence in Kalawana watershed. 


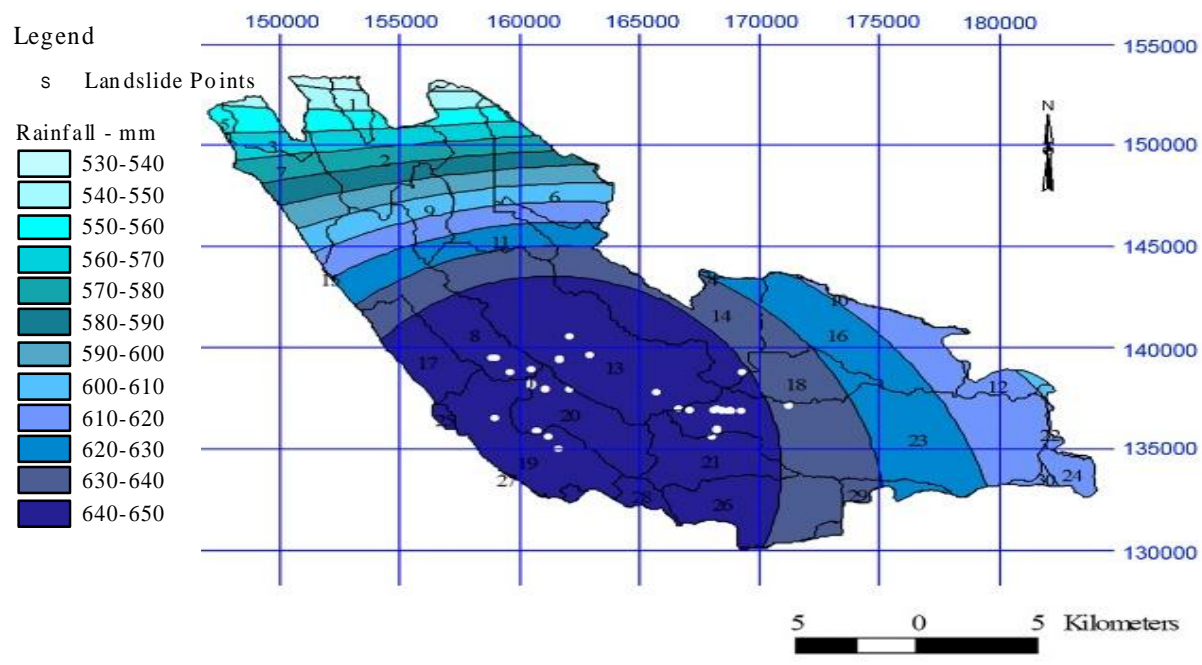

Fig. 12. Contouring of three day maximum rainfall pattern within the Kalawana division
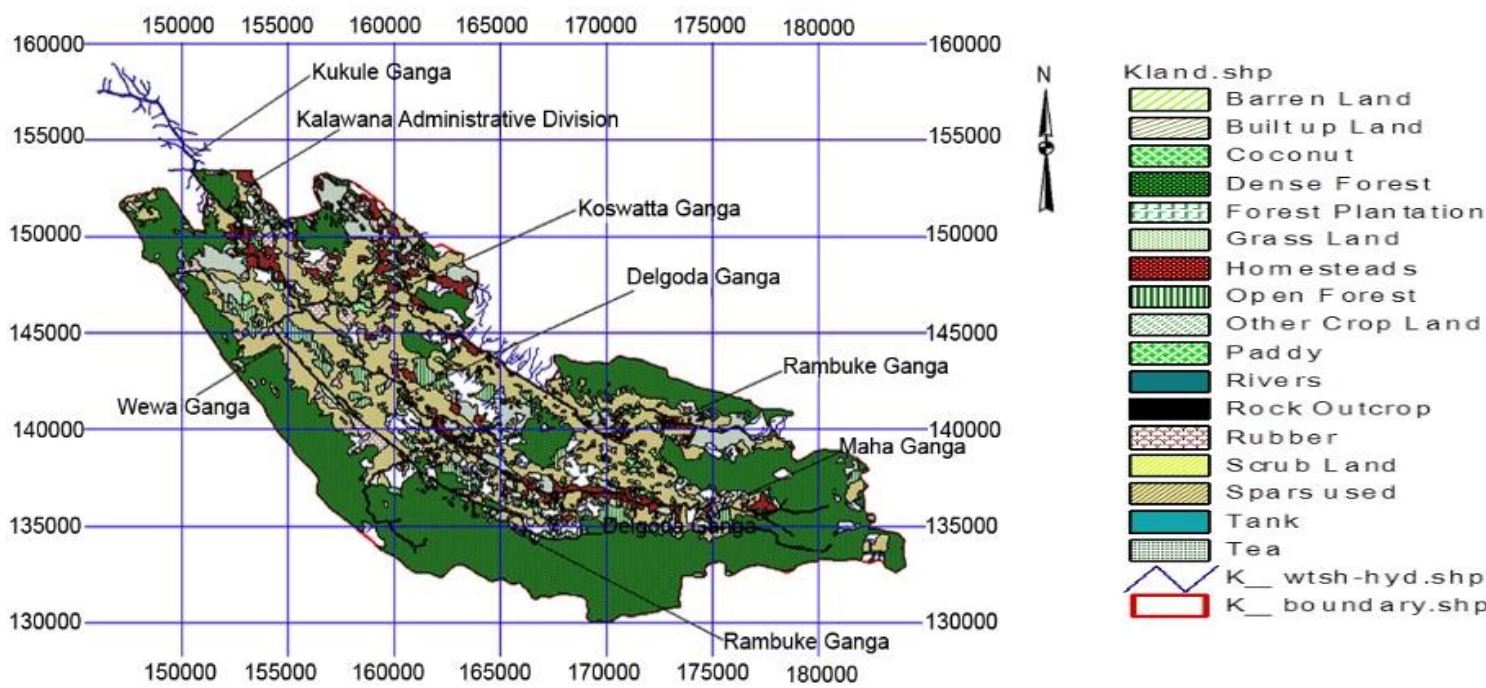

Fig. 13. Relationship of land use and landslide occurrence in Kalawana watershed.

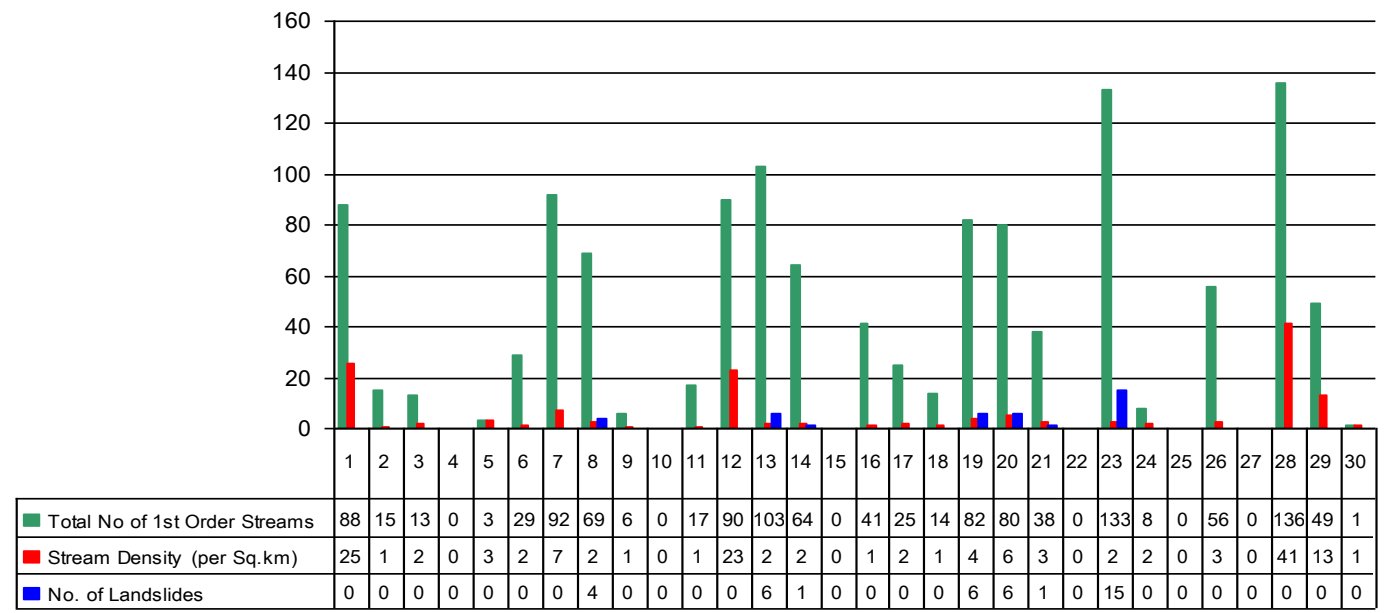

Fig. 14. Relationship with the stream density (according to 1st order stream) and landslide occurrence in Kalawana watershed 


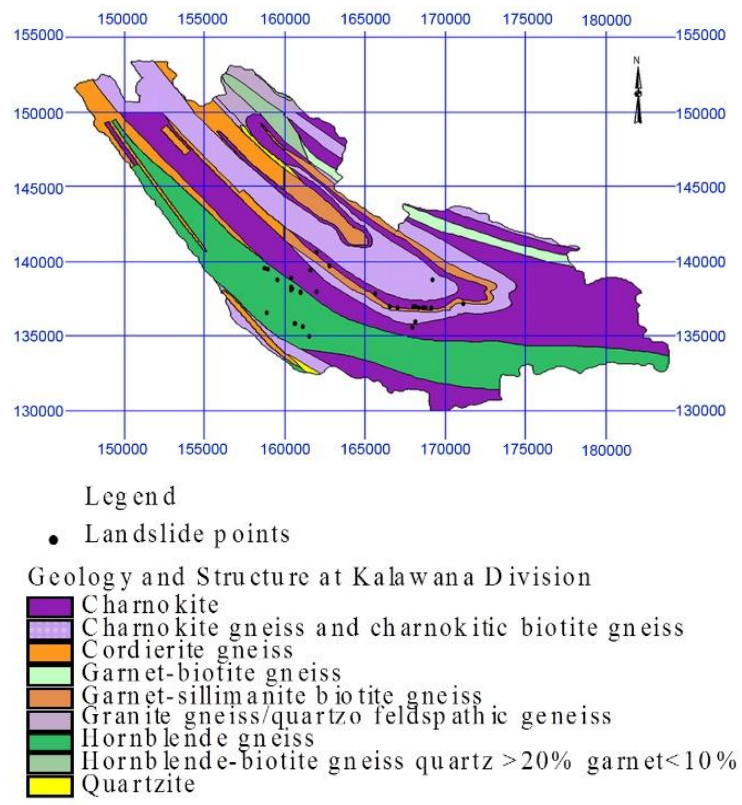

Fig. 15. Visual interpretation of bedrock geology map and significance of landslide in Kalawana watershed.

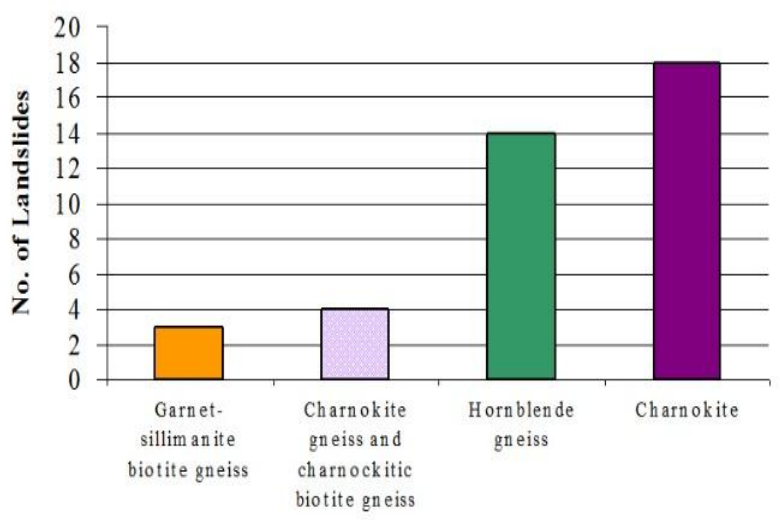

Fig. 16. Relationship with the rock type and landslide occurenance in Kalawana watershed

\section{PRIORITIZING OF FACTORS RESPONSIBLE FOR LANDSLIDING}

An important step is the conversion of categorical parameters into numerical ones and ranking them according to their contribution to the instability (Carrara, 1983). Prioritizing of factors responsible for the landslides is an essential process in landslide susceptibility analysis. This allows the scientist to recognize how important each requirement is. If resources are short, the least important requirements may have to be left out. Considering recent findings and varous explanations, factors contributing to destabilization of slopes are slope (S), rainfall, precipitation potential (R), hydrology, considering the number of 1 st order streams within the selected catchment $(\mathrm{H})$; road buffer considering the distance away from the edge of the road (RB); bedrock geology, due to dipping and foliation issues (BG), shear strength of the top overburdened soil (SS); and landuse (L).

\section{RELATIVE IMPORTANCE OF PAIRWISE COMPARISION}

An Analytic Hierarchy Process (AHP) is a quantitative technique for multiple criteria decision making (Saaty, 1994). It provides a convenient way to quantify the qualitative aspects, thus eliminating subjectivity in the outcome. The Analytic Hierarchy Process is a theory of measurement through pairwise comparisons (Barzilai, 1997) and relies on the judgments of experts to derive priority scales (Saaty, 2008). In addition, factor prioritizing quantitative susceptibility assessment may be either relative or unqualified. Therefore, sub factor assessment will evaluate the primary significance of the major scales that measure intangibles in relative terms. The comparisons are made using a scale of absolute judgments that represents, how much more, one element dominates another with respect to a given attribute. The judgments may be inconsistent, and how to measure inconsistency and improve the judgments, when possible, to obtain better consistency, is a concern of the AHP. The overall approach of the AHP is given below.

\section{DEFINING A NUMERICAL MATRIX}

The Analytic Hierarchy Process (AHP) is a mathematically based process that can be used to prioritize requirements. Its applicability is in the latter portions of the requirements phase, after the requirements are elicited. The requirements will likely have to be organized 
using a hierarchy such that not just the requirements can be categorized but also such that their respective categories can be prioritized.

A comparison matrix is consistent if all its elements $a_{i j}$ comparing alternatives $i$ and $j$, respect the reciprocity [1] and transitivity [2] rules:

\section{Reciprocity}

$a_{i j}=1 / a_{j i}$

where $i, j$ are any alternatives of the matrix

Example: If rainfall is twice as important as hydrology $\left(a_{1,2}=2\right)$, then hydrology is half as important as rainfall $\left(a_{2,1}=1 / 2\right)$

\section{Transitivity}

$a_{i, j}=a_{i, k} \cdot a_{k, j}$

where $i, j$ and $k$ are any alternatives of the matrix.

Example: Suppose rainfall is twice as important as hydrology $\left(a_{1,2}=2\right)$ and hydrology is four times as important as bedrock geology $\left(a_{2,3}=4\right)$. If rainfall is eight times as important as bedrock geology $\left(a_{1,3}=\right.$ 8 ), the transitivity rule is respected.

A matrix is reciprocal, if its inferior part is reciprocal to the superior part and all the elements of the principal are equal to 1 . Therefore, the transitivity needs to be tested for the upper part of the matrix only:

$a_{i, j}=a_{i, k} \cdot a_{k, j} \quad, \quad$ for $j>k>i$ [3]

Hence, for each element $a_{i, j}$ a number of $j$ $(i+1)$ equations [1] have to be respected.

Example: The comparison $a_{2,5}$ has to respect equations $a_{2,5}=a_{2,3} \cdot a_{3,5}$ and $a_{2,5}=a_{2,4} \cdot a_{4,5}$

These equations can be expressed exclusively in terms of the first diagonal above the principal diagonal (i.e. $a_{12}, a_{23}, \ldots, a_{n-1 n}$ ):

$a_{i, j}=a_{i, i+1} \cdot a_{i+1, i+2} \cdot \cdots \quad \ldots \quad \cdot a_{j-1, j}$ [4]
All the priorities derivation methods provide the same priorities with consistent matrices. In the case of inconsistencies, they can be arranged in three main categories:

\section{(a) Eigenvalue approach}

The eigenvalue approach researches the dominance of a solution. It estimates that small perturbations in a consistent matrix induce small changes on the priorities. Two methods have been established: the maximal right eigenvalue method and the maximal left eigenvalue method.

\section{(b) Distance minimization}

These methods try to minimise the error. A minimum can be calculated in various metrics. The most popular is the logarithmic least squares method where the geometric mean is the sole solution.

\section{(c) Approximate method (Normalised} values)

Many other methods have been proposed without theoretical fundamentals with inconsistent matrices. One of these is the method of the mean of the normalised values.

\section{EVALUATION OF RESULTS}

\section{FACTOR PRIORITIZING AND DETAIL ANALYSIS}

Factor prioritizing requirements were determined using the Analytical Hierarchy Process (AHP) for the Kalawana watershed. In this method, at first, for the reason of determining different factor preferences and converting them into quantitative values, valued judgments are used. In this case, the preference of a factor as compared with the other factor are tabulated as in Table 1, and these judgments are changed into quantitative values from 1 to 9 . 
Table 1: Factors preference and conversion into quantitative values from 1 to 9 .

\begin{tabular}{lc}
\hline $\begin{array}{l}\text { Preference of a factor as } \\
\text { compared with the other }\end{array}$ & $\begin{array}{c}\text { Numerical } \\
\text { value }\end{array}$ \\
\hline Extremely preferred & 9 \\
Very strongly preferred & 7 \\
Strongly preferred & 5 \\
Moderately preferred & 3 \\
Equally preferred & 1 \\
Intervals between preferences & $2,4,6,8$ \\
\end{tabular}

The downward and outward movement of soil mass from sloping mountain areas is the most prominent factor and that can be chosen to be studied in detail. The next significant factor was considered to be soil properties, the restoring component of a potentially unstable soil mass stabilized through the in-situ properties of soil and type of vegetation (Dias et al., 2014).
Therefore, landuse parameters indicate tendency of soil saturation potential, loading and unloading, improper management of slopes etc. All other factors such as bedrock geology, landuse, hydrology 1 (rainfall), hydrology 2 (1st order streams) and road buffer are considered as increasing tendencies for landslide susceptibility in quantification assessment. The creation of a digital terrain model was shown to be very important for a relevant landslide susceptibility analysis made in larger scale than 1: 50 000. Therefore, areas with highest landslide susceptibility were chosen to be studied in detail from the point view of slope angle or the combination of angle and slope aspect (Dias et al., 2014). Considering all of the above explanations, factors contributing to destabilization of slopes are slope (S), rainfall, precipitation potential (R), hydrology, considering the number of 1st order streams within the selected catchment $(\mathrm{H})$; road buffer considering the distance away from the edge of the road (RB); bedrock geology, due to dipping and foliation issues (BG), shear strength of the top overburdened soil (SS); and landuse (L).

Table 2: Reciprocity and transitivity of factors in landslide susceptibility analysis.

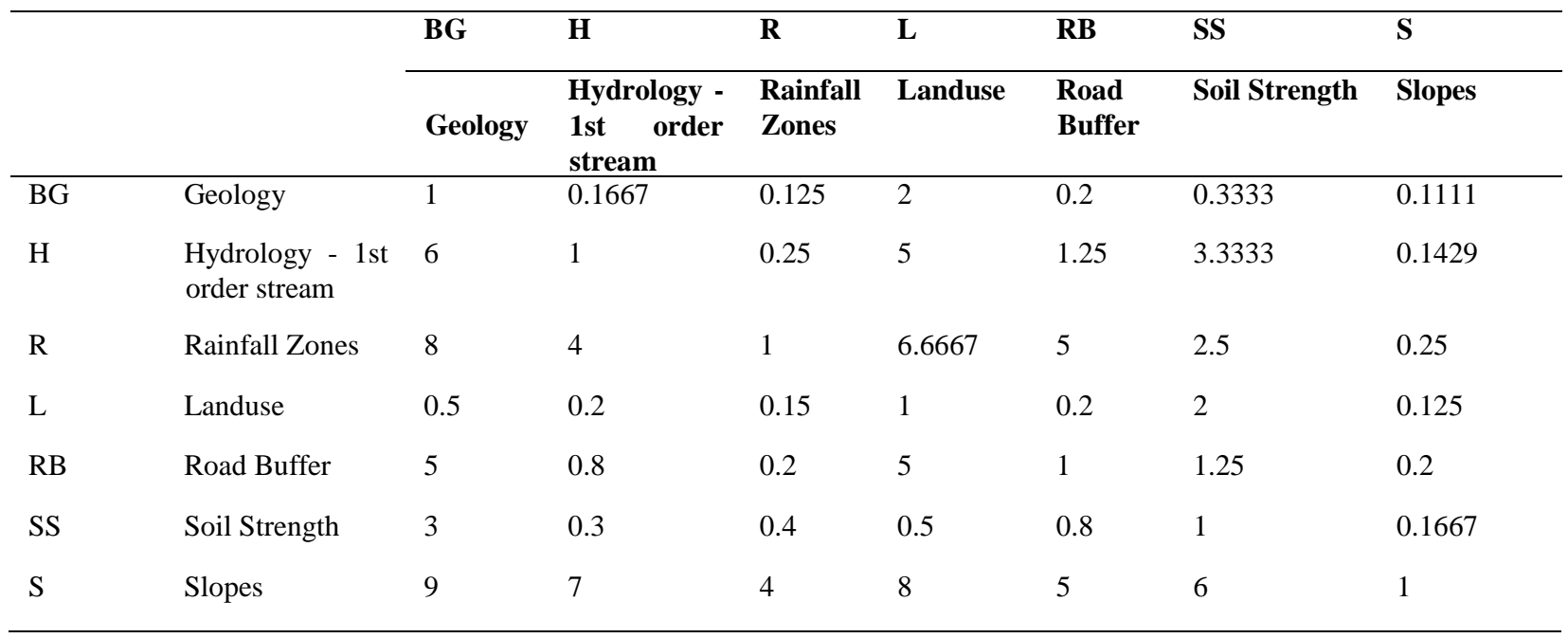


The Analytical Hierarchy Process was considered for the primary development of the susceptibility coefficient. All sub ratings were calibrated by defining the closest combination to actual landslides distribution. The methodology adopted in this study was an approximation method with a normalizing matrix for the evaluation of landslide susceptibility. The mean of the normalised values does not have a theoretical foundation for inconsistent matrices; it is a good approximation of the right eigenvalue method.Similarly, reciprocity and transitivity were identified within the state of nature factors as shown above. A few attempts will be made correct the primary judgment of pair wise comparisons of factor contributions to landslides.

Table 3: Factor preference in ascending order and calculated weighted coefficients by the arithmetic mean method for calculating the factors weights.

\begin{tabular}{lll}
\hline Notation & \multicolumn{1}{c}{$\begin{array}{c}\text { State of Nature/Factor } \\
\text { Map }\end{array}$} & $\begin{array}{c}\text { Factor } \\
\text { Weight } \\
(\boldsymbol{X})\end{array}$ \\
\hline$X 1$ & Geology & 0.0322 \\
$X 2$ & Hydrology - 1st order stream & 0.1207 \\
$X 3$ & Rainfall Zones & 0.2275 \\
$X 4$ & Landuse & 0.0414 \\
$X 5$ & Road Buffer & 0.0963 \\
$X 6$ & Soil Strength & 0.0574 \\
$X 7$ & Slopes & 0.4246 \\
\hline
\end{tabular}

Table 4: Evaluation of sub factor for geology map .

\begin{tabular}{lllcc}
\hline $\begin{array}{c}\text { Decision } \\
\text { Tree }\end{array}$ & Geology & Rating & $\boldsymbol{X 1}$ & $\begin{array}{c}\text { Map } \\
\text { Weight } \\
\text { X1 }\end{array}$ \\
\hline Slightly & E & 0.0017 & 0.0322 & 0.0001 \\
Low & D & 0.0505 & 0.0322 & 0.0016 \\
Moderate & C & 0.1528 & 0.0322 & 0.0049 \\
High & B & 0.2779 & 0.0322 & 0.0090 \\
V High & A & 0.5171 & 0.0322 & 0.0167 \\
\hline
\end{tabular}

Table 5: Evaluation of sub factor for hydrology-considering $1^{\text {st }}$ order streams map unit.

\begin{tabular}{lllcc}
\hline $\begin{array}{c}\text { Decision } \\
\text { Tree }\end{array}$ & $\begin{array}{c}\text { Hydrology } \\
\text { 1st Order } \\
\text { stream }\end{array}$ & Rating & $\boldsymbol{X 2}$ & $\begin{array}{c}\text { Map } \\
\text { Weight } \\
\mathbf{X 2}\end{array}$ \\
\hline Slightly & $0-25$ & 0.0008 & 0.1207 & 0.0001 \\
Low & $26-50$ & 0.0236 & 0.1207 & 0.0029 \\
Moderate & $51-75$ & 0.0895 & 0.1207 & 0.0108 \\
High & $76-100$ & 0.2662 & 0.1207 & 0.0321 \\
V High & $>100$ & 0.6199 & 0.1207 & 0.0748 \\
\hline
\end{tabular}

Table 6: Evaluation of sub factor for rainfall $\&$ watershed map unit.

\begin{tabular}{llccc}
\hline $\begin{array}{c}\text { Decision } \\
\text { Tree }\end{array}$ & $\begin{array}{c}\text { Rainfall \& } \\
\text { Watershed }\end{array}$ & Rating & $\boldsymbol{X 3}$ & $\begin{array}{c}\text { Map } \\
\text { Weight } \\
\mathbf{X 3}\end{array}$ \\
\hline Slightly & $500-550$ & 0.0004 & 0.2275 & 0.0001 \\
Low & $550-600$ & 0.0268 & 0.2275 & 0.0061 \\
Moderate & $600-625$ & 0.2230 & 0.2275 & 0.0507 \\
High & $625-650$ & 0.7498 & 0.2275 & 0.1706 \\
\hline
\end{tabular}

Table 7: Sub factor for soil strength map unit.

\begin{tabular}{llccc}
\hline $\begin{array}{c}\text { Decision } \\
\text { Tree }\end{array}$ & $\begin{array}{c}\text { Soil } \\
\text { Strength }\end{array}$ & Rating & X6 & $\begin{array}{c}\text { Map } \\
\text { Weight } \\
\text { X6 }\end{array}$ \\
\hline Low & $>75$ & 0.0007 & 0.0574 & 0.0000 \\
Moderate & $51-75$ & 0.1294 & 0.0574 & 0.0074 \\
High & $0-50$ & 0.8700 & 0.0574 & 0.0499 \\
\hline
\end{tabular}

Table 8: Sub factor for landuse map unit.

\begin{tabular}{llccc}
\hline $\begin{array}{c}\text { Decision } \\
\text { Tree }\end{array}$ & Landuse & Rating & $\boldsymbol{X 4}$ & $\begin{array}{c}\text { Map } \\
\text { weight } \\
\text { X4 }\end{array}$ \\
\hline Stable & Paddy & 0.0001 & 0.0414 & 0.00000 \\
Slightly & Water & 0.0175 & 0.0414 & 0.0007 \\
Low & Scrub \& & 0.0376 & 0.0414 & 0.0016 \\
& Grass & & & \\
Moderate & Plantations & 0.0747 & 0.0414 & 0.0031 \\
High & Forest & 0.1679 & 0.0414 & 0.0069 \\
V High & Homestead & 0.7021 & 0.0414 & 0.0290 \\
& $\&$ Barren & & & \\
\hline
\end{tabular}


Table 9: Sub factor for road buffer map units.

\begin{tabular}{lllcc}
\hline $\begin{array}{c}\text { Decision } \\
\text { Tree }\end{array}$ & $\begin{array}{c}\text { Buffer } \\
\text { Distance }\end{array}$ & Rating & $\boldsymbol{X 5}$ & $\begin{array}{c}\text { Map } \\
\text { Weight } \\
\mathbf{X 5}\end{array}$ \\
\hline Slightly & $200-300$ & 0.0005 & 0.0963 & 0.0001 \\
Low & $>300$ & 0.0365 & 0.0963 & 0.0035 \\
Moderate & $100-200$ & 0.1653 & 0.0963 & 0.0159 \\
High & $0-100$ & 0.7976 & 0.0963 & 0.0768 \\
\hline
\end{tabular}

Table 10: Sub factor of slope map units.

\begin{tabular}{lllcc}
\hline $\begin{array}{c}\text { Decision } \\
\text { Tree }\end{array}$ & Slopes & Rating & $\boldsymbol{X 7}$ & $\begin{array}{c}\text { Map } \\
\text { Weight }\end{array}$ \\
& & & & $\mathbf{X 7}$ \\
\hline Stable & $0-12$ & 0.0009 & 0.4246 & 0.0004 \\
Slightly & $>50$ & 0.0186 & 0.4246 & 0.0079 \\
Low & $42-52$ & 0.0588 & 0.4246 & 0.0250 \\
Moderate & $32-42$ & 0.1174 & 0.4246 & 0.0499 \\
High & $12-22$ & 0.2776 & 0.4246 & 0.1179 \\
Extremely & $22-32$ & 0.5266 & 0.4246 & 0.2236 \\
High & & & & \\
\hline
\end{tabular}

\section{COEFFICIENT OF LANDSLIDE SUCEPTIBILITY}

The simplification was made through sub factor evaluations and the susceptibility coefficient was worked out according to equations [5] and [6]. The simplification of sub factor evaluation and reciprocity and transmisitivitty of factors in the landslide suceptability analysis is shown in the Table 2 and Table 3. The evaluation of sub factor coefficients are shown in Table 4 to Table 10. After evaluating the area with regard to the seven factors, at present, the values of the seven factor classes $\mathrm{X}$ are multiplied by derived individual weights for each factor (w1.....w7) and are then summed together.

Then the total value M1 for each pixel and the regional model will be derived:

$\mathrm{M} 1=\mathrm{w}_{1} X_{1}+\mathrm{w}_{2} X_{2}+\mathrm{w}_{3} X_{3}+\mathrm{w}_{4} X_{4}+\mathrm{w}_{5} X_{5}+$ $\mathrm{w}_{6} X_{6}+\mathrm{w}_{7} X_{7}$
By replacing the combined weights (w1.....w7) that were estimated previously, the final model was derived:

$\mathrm{M}=\mathrm{w}_{1} \mathrm{X}_{1}+\mathrm{w}_{2} \mathrm{X}_{2}+\mathrm{w}_{3} \mathrm{X}_{3}+\mathrm{w}_{4} \mathrm{X}_{4}+\mathrm{w}_{5} \mathrm{X}_{5}+$ $\mathrm{w}_{6} \mathrm{X}_{6}+\mathrm{w}_{7} \mathrm{X}_{7}$

Where: $M=$ Susceptibility coefficient

$X 1 \ldots X 7=$ are related to slope, shear strength, bedrock geology, landuse, rainfall, hydrology $2\left(1^{\text {st }}\right.$ order streams) and road buffer and, $\mathrm{w} 1 \ldots \mathrm{w} 7=$ are the weights related to each $\mathrm{X} 1 \ldots . \mathrm{X} 7$ factors are shown in Table 11 below. $\mathrm{M}$ variations from 0 to 1 as shown in Table 14.

Table 11: Final weighted coefficients by the arithmetic mean method for calculating the landslide suceptability under WAA.

\begin{tabular}{lll}
\hline Notation & \multicolumn{1}{c}{$\begin{array}{c}\text { State of } \\
\text { Nature/Factor } \\
\text { Map }\end{array}$} & $\begin{array}{l}\text { Final weighted } \\
\text { coefficients (X) }\end{array}$ \\
\hline$X 1$ & Geology & 0.0323 \\
$X 2$ & $\begin{array}{l}\text { Hydrology - 1st } \\
\text { order stream }\end{array}$ & 0.1207 \\
$X 3$ & Rainfall Zones & 0.2275 \\
$X 4$ & Landuse & 0.0413 \\
$X 5$ & Road Buffer & 0.0963 \\
$X 6$ & Soil Strength & 0.0573 \\
$X 7$ & Slopes & 0.4247 \\
\hline
\end{tabular}

\section{RESULTS \& DISCUSSION}

The method of evaluating factor weights and their relative importance using the multi criteria decision making approach is the most conventional approach of landslide susceptibility mapping. An effort was made to model the selected area according to the WAA and appropriate weights were assigned according to the normalized method defined under the AHP. The AHP was to facilitate an understanding of landslide significance with 
Table 12: Reclassified Class, No of pixels,Pixel Area, Min, Max, Mean - value of the class.

\begin{tabular}{|c|c|c|c|c|c|c|c|}
\hline VALUE & COUNT & AREA & MIN & MAX & MEAN & STD & SUM (Area) \\
\hline 1 & 5831 & 583100 & 0.0362 & 0.0449 & 0.0429 & 0.0009 & 250.4042 \\
\hline 2 & 20397 & 2039700 & 0.0457 & 0.053 & 0.0503 & 0.0025 & 1026.5654 \\
\hline 3 & 42584 & 4258400 & 0.0536 & 0.0617 & 0.0572 & 0.0029 & 2434.3342 \\
\hline 4 & 8251 & 825100 & 0.0625 & 0.0702 & 0.0644 & 0.0013 & 531.2206 \\
\hline 5 & 18899 & 1889900 & 0.0707 & 0.0789 & 0.0769 & 0.0016 & 1453.5338 \\
\hline 6 & 66596 & 6659600 & 0.0707 & 0.0876 & 0.0842 & 0.0023 & 5609.5869 \\
\hline 7 & 295792 & 29579200 & 0.0792 & 0.0961 & 0.0909 & 0.0022 & 26874.4121 \\
\hline 8 & 213172 & 21317200 & 0.0962 & 0.1047 & 0.0987 & 0.0025 & 21032.1055 \\
\hline 9 & 93224 & 9322400 & 0.1048 & 0.1133 & 0.1082 & 0.003 & 10086.6357 \\
\hline 10 & 17267 & 1726700 & 0.1135 & 0.1217 & 0.1189 & 0.0024 & 2052.4028 \\
\hline 11 & 44159 & 4415900 & 0.1221 & 0.1304 & 0.1266 & 0.0024 & 5591.6182 \\
\hline 12 & 136479 & 13647900 & 0.1305 & 0.1389 & 0.1358 & 0.0021 & 18533.75 \\
\hline 13 & 218007 & 21800700 & 0.1391 & 0.1475 & 0.1438 & 0.0021 & 31351.8711 \\
\hline 14 & 195306 & 19530600 & 0.1477 & 0.156 & 0.1526 & 0.0024 & 29798.6484 \\
\hline 15 & 197170 & 19717000 & 0.1564 & 0.1647 & 0.16 & 0.0024 & 31550.4824 \\
\hline 16 & 39532 & 3953200 & 0.1648 & 0.1731 & 0.1692 & 0.0019 & 6687.3604 \\
\hline 17 & 79246 & 7924600 & 0.1734 & 0.1818 & 0.1791 & 0.0019 & 14196.4502 \\
\hline 18 & 89003 & 8900300 & 0.182 & 0.1903 & 0.187 & 0.0018 & 16642.043 \\
\hline 19 & 118239 & 11823900 & 0.1905 & 0.199 & 0.1959 & 0.0024 & 23163.4531 \\
\hline 20 & 236444 & 23644400 & 0.1991 & 0.2075 & 0.2047 & 0.0018 & 48407.8711 \\
\hline 21 & 241632 & 24163200 & 0.2076 & 0.2161 & 0.2111 & 0.0024 & 51019.832 \\
\hline 22 & 52847 & 5284700 & 0.2163 & 0.2247 & 0.2194 & 0.0023 & 11596.5332 \\
\hline 23 & 17666 & 1766600 & 0.2248 & 0.2329 & 0.2279 & 0.0018 & 4025.5422 \\
\hline 24 & 23108 & 2310800 & 0.2333 & 0.2418 & 0.2388 & 0.0024 & 5518.6299 \\
\hline 25 & 51279 & 5127900 & 0.242 & 0.2504 & 0.2477 & 0.0022 & 12703.165 \\
\hline 26 & 136531 & 13653100 & 0.2507 & 0.2589 & 0.255 & 0.0029 & 34821.293 \\
\hline 27 & 82360 & 8236000 & 0.259 & 0.2675 & 0.2625 & 0.0028 & 21617.7832 \\
\hline 28 & 98426 & 9842600 & 0.2678 & 0.2761 & 0.2708 & 0.0017 & 26654.4082 \\
\hline 29 & 106266 & 10626600 & 0.2764 & 0.2846 & 0.2773 & 0.001 & 29464.3281 \\
\hline 30 & 14929 & 1492900 & 0.2849 & 0.2932 & 0.2888 & 0.0026 & 4311.1978 \\
\hline 31 & 70393 & 7039300 & 0.2933 & 0.3017 & 0.2972 & 0.0026 & 20917.332 \\
\hline 32 & 122708 & 12270800 & 0.3019 & 0.3103 & 0.3058 & 0.0022 & 37526.8711 \\
\hline 33 & 119723 & 11972300 & 0.3104 & 0.3189 & 0.3137 & 0.0018 & 37554.4141 \\
\hline 34 & 73966 & 7396600 & 0.3192 & 0.3273 & 0.3216 & 0.0014 & 23785.6465 \\
\hline 35 & 13583 & 1358300 & 0.3277 & 0.3359 & 0.3307 & 0.0019 & 4491.3359 \\
\hline 36 & 15940 & 1594000 & 0.3363 & 0.3445 & 0.3402 & 0.0022 & 5422.1519 \\
\hline 37 & 41899 & 4189900 & 0.3448 & 0.3532 & 0.3498 & 0.0022 & 14654.9883 \\
\hline 38 & 76620 & 7662000 & 0.3533 & 0.3618 & 0.3578 & 0.0025 & 27418.0137 \\
\hline 39 & 44870 & 4487000 & 0.3619 & 0.3703 & 0.368 & 0.0027 & 16513.25 \\
\hline 40 & 81383 & 8138300 & 0.3707 & 0.3789 & 0.3763 & 0.0023 & 30627.6777 \\
\hline 41 & 7711 & 771100 & 0.379 & 0.3873 & 0.03825 & 0.0027 & 2949.1047 \\
\hline 42 & 22267 & 2226700 & 0.3876 & 0.3959 & 0.3926 & 0.0026 & 8741.2393 \\
\hline 43 & 29166 & 2916600 & 0.3962 & 0.4044 & 0.3997 & 0.0015 & 11657.0518 \\
\hline 44 & 17975 & 1797500 & 0.4047 & 0.4131 & 0.4068 & 0.0024 & 7312.2729 \\
\hline 45 & 38849 & 3884900 & 0.4134 & 0.4217 & 0.418 & 0.0036 & 16239.6318 \\
\hline 46 & 6942 & 694200 & 0.422 & 0.4302 & 0.4244 & 0.0018 & 2946.4832 \\
\hline 47 & 5610 & 561000 & 0.4304 & 0.4388 & 0.4327 & 0.0017 & 2427.696 \\
\hline 48 & 2715 & 271500 & 0.4398 & 0.447 & 0.4423 & 0.0012 & 1200.9774 \\
\hline 49 & 2396 & 239600 & 0.4477 & 0.4549 & 0.4502 & 0.0008 & 1078.7238 \\
\hline 50 & 1059 & 105900 & 0.4563 & 0.4644 & 0.4608 & 0.0022 & 487.9787 \\
\hline 51 & 1694 & 169400 & 0.4647 & 0.4731 & 0.4691 & 0.0027 & 794.5992 \\
\hline 52 & 2189 & 218900 & 0.4742 & 0.4812 & 0.477 & 0.0018 & 1044.0708 \\
\hline 53 & 251 & 25100 & 0.4819 & 0.4894 & 0.4839 & 0.0023 & 121.4679 \\
\hline 54 & 164 & 16400 & 0.4915 & 0.4985 & 0.4944 & 0.0034 & 81.075 \\
\hline 55 & 781 & 78100 & 0.4994 & 0.5069 & 0.5053 & 0.0021 & 394.6008 \\
\hline 56 & 795 & 79500 & 0.5081 & 0.5153 & 0.5128 & 0.0021 & 407.6737 \\
\hline 57 & 3584 & 358400 & 0.5163 & 0.5246 & 0.522 & 0.0025 & 1870.9792 \\
\hline 58 & 2725 & 272500 & 0.5251 & 0.5329 & 0.53 & 0.0034 & 1444.3405 \\
\hline 59 & 849 & 84900 & 0.5333 & 0.5408 & 0.5373 & 0.0037 & 456.1767 \\
\hline 60 & 7 & 700 & 0.5419 & 0.5419 & 0.5419 & 0 & 3.7933 \\
\hline 61 & 731 & 73100 & 0.5556 & 0.5584 & 0.5575 & 0.0013 & 407.5212 \\
\hline 62 & 1150 & 115000 & 0.5605 & 0.5659 & 0.5628 & 0.0024 & 647.2259 \\
\hline 63 & 4589 & 458900 & 0.568 & 0.575 & 0.5706 & 0.0034 & 2618.634 \\
\hline 64 & 4483 & 448300 & 0.5771 & 0.5846 & 0.5811 & 0.0037 & 2605.199 \\
\hline
\end{tabular}


the use of factor map overlay criteria and determination of landslide susceptibility coefficients for each contributing extrinsic factor. To this end multi criteria decisions were made considering topography and slope with various combinations slopes; bedrock geology as a function of slope and rock type; $1^{\text {st }}$ order stream density as a function of sub catchment, landuse as a sensitive factor in a catchment; road buffer or slope distance away from center of the road; precipitation potential as a function of rainfall zone and stability of top soil cover as a function of combined cohesion strength of soil and those were considered as primary and secondary factors responsible for susceptibility. Each factor used and the frequency of occurrence were compared before deriving weights.

The defined average weights explain how well the model estimated a real state of slope instability statistically. The cumulative values of pixels frequencies of lanslides hazard susceptibility assessment using normalized method of approach of the AHP includes class, number of pixels, pxel area, mean value of the class, maximum value of the class and statistical mean of the class as recorded similar to Table 12 .

By the AHP method, the entire geographical informations and data were sub catogorised in to into seven major factor maps of slope, geology hydrology 1(rainfall), hydrology 2(1st order stream), road buffer and landuse. Then these factors are weighted based on their importance, and eventually the prepared layers are assembled, cumulative pixel frequencies are evaluated for the final map generation work. To obtain the relative ranks for each prediction pattern, the calculated index values of all cells in the study area were sorted in descending order. Then the ordered cell values were divided into 64 classes with accumulated reasonable interpreted intervals. The primary set of levels of the susceptibility curve creates the prediction accuracy qualitatively as shown in Fig. 17.
In this approach, the weight of each layer depends on the judgment of experts and produces an individual significance of sub factors and ultimately links to the generation of the final susceptibility coefficient as in Table 13.

Table 13: Landslide susceptibility reclassified results - Std deviation $1 / 2$ reduced to 5 classes

\begin{tabular}{lllll}
\hline Class & Class_Lable & Count & $\begin{array}{c}\text { \% } \\
\text { Area }\end{array}$ & $\begin{array}{c}\text { Number of } \\
\text { landslides } \\
\text { recorded } \\
\text { in 2003 }\end{array}$ \\
\hline 1 & $0.036-0.146$ & 1461669 & 38.67 & 4 \\
2 & $0.146-0.256$ & 719978 & 18.99 & 2 \\
3 & $0.256-0.365$ & 861153 & 22.8 & 12 \\
4 & $0.365-0.475$ & 615242 & 16.3 & 6 \\
5 & $0.475-0.585$ & 122367 & 3.24 & 15 \\
& and over & 3780409 & 100 & 39 \\
\hline
\end{tabular}

The numerical rating and integration of data only concludes if the reasonable observations of verification data (old landslides). That means more precise the judgment, the more compatible the produced map is in reality. The landslide susceptibility analysis result was validated using known landslide locations. Validation was performed by comparing the known landslide location data with the landslide susceptibility map. The study has limited data on landslide and therefore accuracy of the observations do not strictly difind the high accurate susceptibility rating. It is indeed possible to achieve more accuracy by the adition and creation of factor maps, which are satisfactory with numerical logic in AHP. In addition, use of accurate eveidences and development of value judgement matric will help in advance to improve the accuracy of the AHP methodology.

With regard to this analysis, the Kalawana watershed has been divided into five susceptibility classes as in Table 14 . 
Table 14: Landslide suceptibility categories with the AHP method of evaluation at Kalawana.

\begin{tabular}{|c|c|c|}
\hline $\begin{array}{c}\text { Value of } \\
\text { Suceptibility } \\
\text { Coefficient }\end{array}$ & Class & Catogory Name \\
\hline $0.0 \mathrm{M} \quad 0.146$ & 1 & No Susceptibility \\
\hline $0.146<\mathrm{M} 0.256$ & 2 & Low Susceptibility \\
\hline $0.256<\mathrm{M} 0.365$ & 3 & $\begin{array}{l}\text { Moderately } \\
\text { Susceptibility }\end{array}$ \\
\hline $0.365<\mathrm{M} 0.475$ & 4 & High Susceptibility \\
\hline $0.475<\mathrm{M} 1$ & 5 & $\begin{array}{l}\text { Very High } \\
\text { Susceptibility }\end{array}$ \\
\hline
\end{tabular}

importance with the input databases. Detailed and comprehensive geographical information databases are required to obtain statistical interpretation and calibration of the model.

Finally, the zoning map of the Kalawana Division watershed using the Analytical Hierarchy Process (AHP) method was derived as Fig. 18 and the overall assessment of sensitivity is given in Table 15 .

\section{FIELD VERIFICATIONS}

Only 39 landslides were used out of 78 case records at Kalawana to calibrate models due to inaccessibility at field.

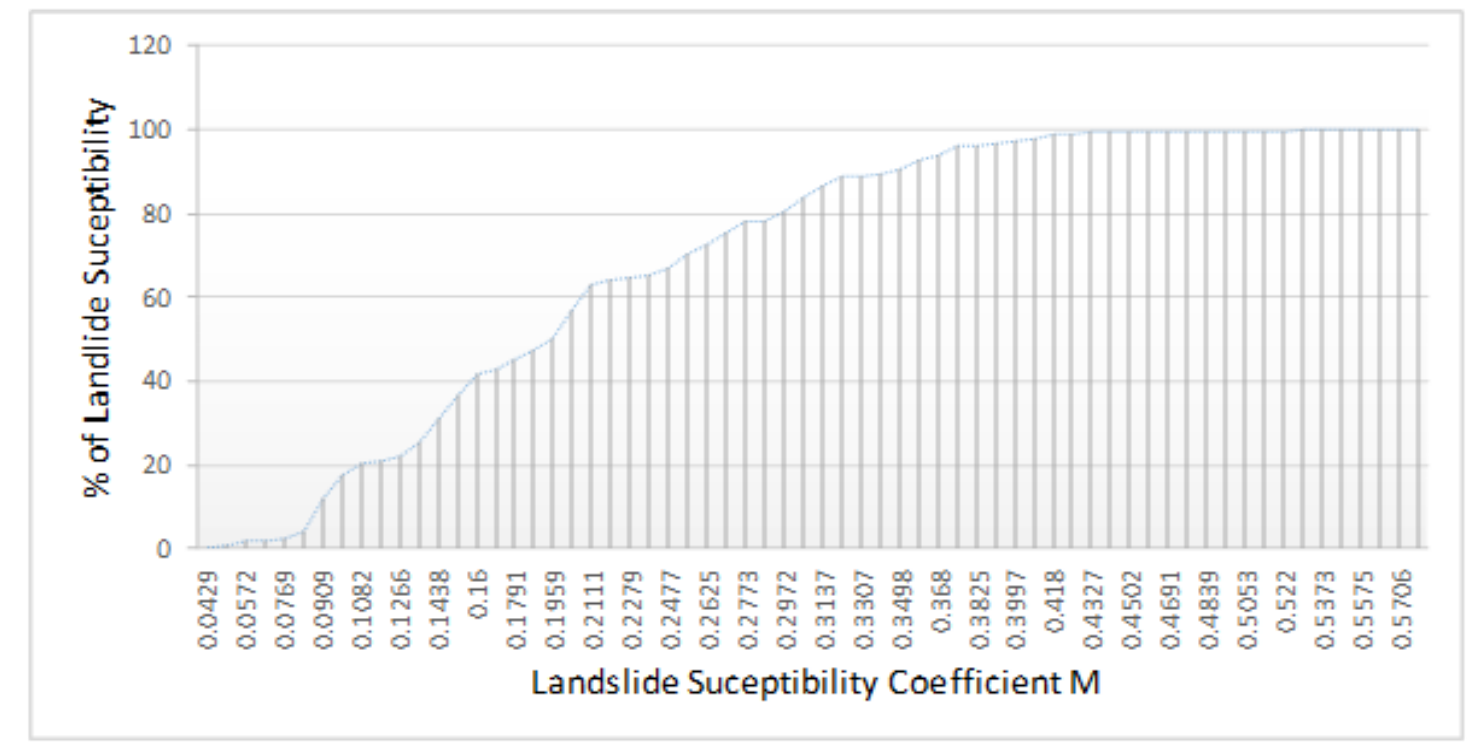

Fig. 17. Illustration of the ranking of stability class with a large database reasonably capable for evaluation of landslide susceptibility.

The analysis fairly well defines areas that intuitively appear to be susceptible to landslides. It was noted that a few landslides occurred on slopes that would not normally be recognized as susceptible to landslides. This means that the methodology missed classifing several of these sites as being landslide-prone due to the site-specific geologic conditions and inaccurate input parameters of soil. The above finding indicates that the variability of conceptual models and their relative
The verification data indicates the variability of the conceptual models and their relative importance with the input databases (Table 15). The detailed and comprehensive geographical information databases are required to obtain the statistical interpretation and calibration of the model. Similarly, soil saturation conditions and the validity of wetness indices within a watershed also create another avenue to calibrate the analytical model with the inputs of other soil parameters. 
Table 15: Landslide susceptibility reclassified results ( Std deviation $1 / 2$ reduced to 5 classes ) and evidence of all landslides occurences.

\begin{tabular}{llllccc}
\hline Class & Class Lable & Susceptibility & Count & \% Area & $\begin{array}{c}\text { Number of } \\
\text { Landslides }\end{array}$ & \% \\
\hline 1 & $0.036-0.146$ & No Susceptibility & 1461669 & 38.67 & 4 & $15.4 \%$ \\
2 & $0.146-0.256$ & Low Susceptibility & 719978 & 18.99 & 2 & \\
\hline 3 & $0.256-0.365$ & Moderately Susceptibility & 861153 & 22.8 & 12 & \multirow{2}{*}{$84.6 \%$} \\
4 & $0.365-0.475$ & High Susceptibility & 615242 & 16.3 & 6 & \\
5 & $\begin{array}{l}0.475-0.585 \\
\text { and over }\end{array}$ & Very High Susceptibility & 122367 & 3.24 & 15 & \\
\hline
\end{tabular}

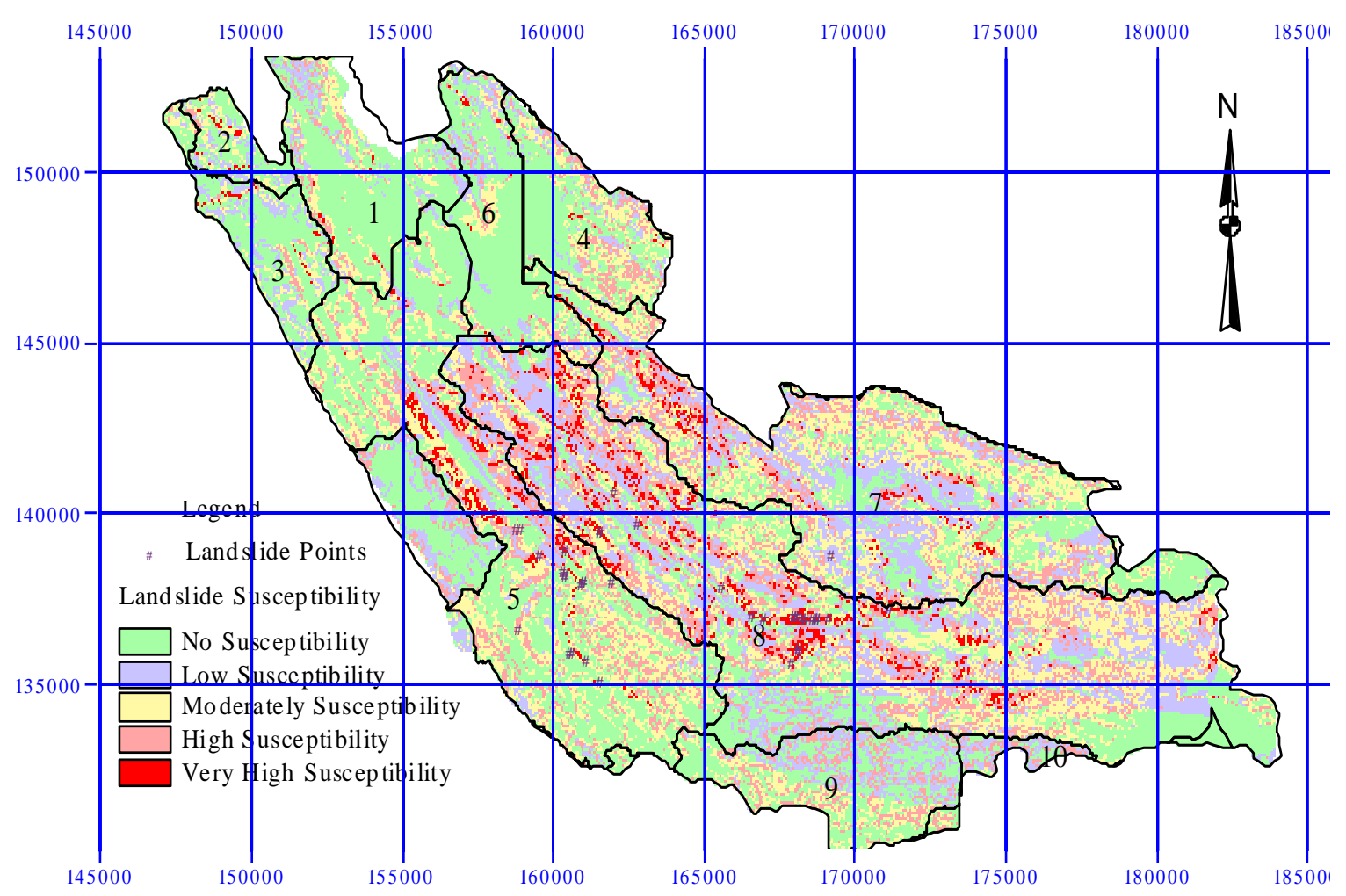

Fig. 18. The Landslide susceptibility map generated through the Weighted Average Analysis Model (WAA) and the landslide susceptibility defind with AHP method of model approach 


\section{CONCLUSIONS}

The defining of landslide susceptibility is a matter of classifying degree of instability potential using the graph of landslide susceptibility coefficient vs percentage of landslide susceptibility. This was based with the old landslide data and also considering sensitivity of occurrences. The study indicates classifying to five number of classes with the ArcGIS facility and occurrences of landslide under each category. The overall assessment is based on 39 old landslides selected and verified at site. In such situation more than $84.6 \%$ of landslide are fall in the categories of moderate susceptibility to high susceptibility.

The accountable losses from landslides are termed landslide vulnerability. This is one component in determining landslide susceptibility in a particular terrain. Since it is a challenging issue to specify a time frame for the occurrence of landslides in any area, the landslide hazard is generally represented by landslide susceptibility. The precision and accuracy of the factor maps are therefore, dependent on the original data, scale transformations, and the processes of compilation of the data. One of the important consideration is that natural changes as well as human-induced changes can affect the interpretation of susceptibility, and that the absence of past or present landslides does not mean that slope failures will not occur in the future. One of the critical observations of the study is a lack of a complete data base of recent occurrences of old landslides on May, 2003.

The satellite technology is ideally suitable for mapping of inaccessible mountainous regions where the majority of old landslides were identified. By using multi-temporal satellite data, landslide prone areas can be compared every year with other prediction variables such as altitude, slope, nearness to settlements, road access and grave sites, and the area most susceptible to landslides in a particular year.
The derived relief parameters can be analyzed using GIS together with other information obtained from remote sensing data, thematic maps and field observation for spatially differentiated terrain properties as a basis for further accuracy of a landslide susceptibility mapping.

\section{ACKNOWLEDGMENTS}

This paper forms an integral part of the research on "Evaluation of Sensitivity of the Combined Hydrological Model for Landslide Susceptibility Risk Mapping in Sri Lanka" being implemented by the Centre for Research \& Development, Central Engineering Consultancy Bureau (CECB) of the Ministry of Mahaweli Development \& Environment. Author would like to acknowledge the financial and technical support originally provided by the Japan Aerospace Exploration Agency (JAXA) and Dr. L Samarakoon, Director, Geo Informatics Centre (GIC) of the Asian Institute of Technology (AIT) in executing this study and extensive support provided in collecting necessary data by the Survey Department of Sri Lanka. Also it is a part of the research leading to MPhil degree which has been registered at the Post Graduate Institute of Science, University of Peradeniya, Sri Lanka and has been granted permission to publish these data. The views expressed in the paper are however those of the authors only. Our grateful thanks are due to the Eng. G. D. A. Piyatilake, Chairman and Eng. K. L. S. Sahabandu, General Manager, Central Engineering Consultancy Bureau for the encouragement.

\section{REFERENCES}

AGS, (2007a) Landslide risk management concepts and guidelines. Australian Geomechanics Society. Australian Geomechanics Vol 37, No 2, pp 1-44.

AGS, (2007b) Guideline for landslide susceptibility, hazard and risk zoning for land 
use planning. Australian Geomechanics. 42: pp 13-36.

AGS, (2007c) Commentary on guideline for landslide susceptibility, hazard and risk zoning for land use planning. Australian Geomechanics. 42: pp 37-58. [online:www. australiangeomechanics .org].

Barzilai, J., (1997) Deriving weights from pairwise comparison matrices, Journal of the Operational Research Society (JORS), Vol. 48 (12), Stockholm, pp. 1226-32.

Bhandari, R.K., Dias, A.A.V., (1996) Rain triggered slope movement as indicators of landslide dynamics. Proc. $7^{\text {th }}$ International Symposium on Landslides; 17-21 June 1996, Trondheim, Norway: Balkema. pp. 1515 1520.

Brumbaugh, Robert W., (1980) Recent geomorphic and vegetal dynamics on Santa Cruz Island, California. In Power, Dennis, ed. A multidisciplinary symposium on the California Islands. Santa Barbara, Calif.: Santa Barbara Museum of Natural History, pp 139-158.

CECB Report, (2003) Landslides case studies at Ratnapura 2003, Operational Professional Combine, CECB, Ministry of Irrigation and Water Management (MIWM).

Carrara, A., (1983) Multivariate methods for landslide hazard evaluation. Mathematical Geology 15, 403-426.

Cooray, P.G., (1994) Geological factors affecting landslides in Sri Lanka; Proc. National Symposium of Landslides in Sri Lanka, Colombo 17-19 ${ }^{\text {th }}$ March, 1994, pp 15-22.

Campbell, Russell H., (1975) Soil slips, debris flows, and rainstorms in the Santa Monica mountains and vicinity, southern California. U.S. Geological Survey Prof. Paper 851, pp 51.

Carrara, A., Cardinali, M., Guzzetti, F., Reichenbach, P., (1995) GIS technology in mapping landslide hazard, in: Carrara, A. and Guzzetti, F.: Geographical information systems in assessing natural hazards, Kluwer, pp 135176.

Cruden, D.M., Varnes, D.J., (1996) Landslide types and processes, in landslides investigation and mitigation, Editors AK Turner. and RL Schuster. Special Report 247, Transport Research Board, National Research Council, Washington D.C., pp 36-75.
Dias, A.A.V., Gunathilaka, A.A.J.K., (2014) Evaluation of sensitivity of the WAA and SINMAP models for landslide susceptibility risk mapping in Sri Lanka, Proceeding of the World Landslide Forum3 (WLF3), Beijing, China, 2-6 June 2014; Volume 2, Landslide Science for a Safer Geoenvironment, pp 167173; ISBN 978-3-319-05049-2; Springer.

Dias, A.A.V., Abayakoon, S.B.S., Bhandari, R.K., (2014) Discrete boundary shear strength of a landslide at high rainfall precipitation zone in Sri Lanka; World landslide forum 3; Beijing, China, China, 2-6 June 2014; Volume 1, Landslide Science for a Safer Geoenvironment, pp 101- 106; ISBN 978-3-319-05049-2; Springer.

Feizizadeh, B., Blaschke, T., Nazmfar, H., Rezaei Moghaddam, M.H., (2013) Landslide Susceptibility Mapping for the Urmia Lake basin, Iran: A multi-Criteria Evaluation Approach using GIS. International Journal of Environmental Research, 7(2): pp 319-336.

Khezri, S., Shahabi, H., Ahmad, B.B., (2013) Application of GIS and Remote sensing Techniques in Assessment of Natural Hazards in the Central Zab Basin, Northwest of Iran. Journal of Basic and Applied Scientific Research, 3(3): pp 765-773.

Moradi, M., Bazyar, M.H., Mohammadi, Z., (2012) GIS-Based landslide susceptibility mapping by AHP Method: A case study, Dena City, Iran. Journal of Basic and Applied Scientific Research, 2(7): pp 6715-6723.

Ramachandra, T.V., Subash Chandran, M.D., Joshi, N.V., Julka, P., Kumar, U., Aithal, B.H., Mesta, P., Rao, G.R., Mukri, V., (2012) Landslide susceptible zone mapping in Uttara Kannada, Central Western Ghats. Sahyadri Conservation Series 7, ENVIS Technical Report: 28. Bangalore, India, pp 131.

Saaty, T.L., (1994) The fundamentals of decision making and priority theory with the analytic hierarchy process, The Analytic Hierarchy Process Series, Vol. VI, RWS Publications, Pittsburgh.

Saaty, T.L., (2008) Decision making with the analytic hierarchy process; Int. J. Services Sciences, Vol. 1, No. 1, pp 83-98.

Shahabi, H., Ahmad, B.B., Khezri, S., (2012) Evaluation and comparison of bivariate and multivariate statistical methods for landslide 
susceptibility mapping (case study: Zab basin). Arabian Journal of Geosciences, 4(1):pp 1-23.

Varnes, D.J., (1978) Slope movement types and processes. In Special Report 176: Landslides: Analysis and Control, editors R.L. Schuster and R.J. Krizek, TRB, National Research Council, Washington, D.C., pp 11-33.

Van Westen, C.J., (2000) The modeling of landslide hazards using GIS, Surveys in Geophysics, Volume 21, Issue 2-3, pp 241-255.

Vitanage, P.W., (1994) Seismicity- Neglected aspects of Sri Lankan landslide studies; Proc. National Symposium of Landslides in Sri Lanka, Colombo 17-19th March, 1994, pp 3140. 